\title{
NEGOTIATION OF IDENTITY: (RE)CONSTRUCTION AND (RE)POSITIONING OF SELF THROUGH LANGUAGE LEARNING
}

\author{
Naho Ishiki \\ Faculty of Management Science, Ubon Ratchathani University, Thailand \\ email: nahohanaho@gmail.com
}

\begin{abstract}
Becoming competent in a language involves more than just academic success, but also multi-faceted aspects of self in a situated context. The core of the study is to explore a participant's experience as a marginalized student in a Filipino American community and the trajectories of learning a foreign language over time and space. Narratives from the participant reflect his approach toward language learning (LL) as well as his motivation behind language learning. This study highlights the impact of foreign language learning experience upon the participant's conflict, negotiation, and transformation of identity. Following his positioning analysis, the paper closely looks at how evaluation by other Filipinos within the community contributes to the participant's ongoing (re)construction and negotiation of identity. How these evaluations encourage or impede his access to heritage language and culture is analyzed based on the participant's use of reported speech. The paper explored whether or not LL can be a way of negotiating and gaining agency, as well as how LL helps a marginalized learner to choose where and how he wants to belong to. The paper also looks at how marginalization motivates language learning, through which the participant seeks to reposition himself. The study also examines how power relationship (marginalized student in a situated context) plays a role in the process of negotiation of identity and meaning-making of self. Results from this study conclude that through experiences in foreign language learning as well as negotiating meanings for being a Japanese as a Foreign Language (JFL) student, the participant gradually shifts to belong to a different community prior to his language learning experience in which he can practice agency and is no longer a marginalized member of his heritage community.
\end{abstract}

Key words: language learning, negotiation of identity, community of practice $(\mathrm{CoP})$

\section{NEGOSIASI IDENTITAS: (RE)KONSTRUKSI DAN (RE)POSISI DIRI MELALUI PEMBELAJARAN BAHASA}

\begin{abstract}
Abstrak: Menjadi kompeten dalam satu bahasa bukan hanya melibatkan keberhasilan akademik, tetapi juga mencakupi banyak aspek diri dalam konteks tertentu. Inti dari penelitian ini adalah untuk mengeksplorasi pengalaman peserta sebagai mahasiswa terpinggirkan dalam masyarakat Filipina Amerika dan lintasan belajar bahasa asing dari waktu ke waktu. Cerita dari peserta mencerminkan pendekatannya terhadap pembelajaran bahasa (PB) serta motivasi yang melatarinya dalam pembelajaran bahasa. Studi ini menyoroti dampak dari pengalaman belajar
\end{abstract}


bahasa asing pada konflik, negosiasi, dan transformasi identitas dari para partisipan. Setelah analisis posisinya, artikel ini melihat dari dekat bagaimana evaluasi oleh orang Filipina lainnya dalam masyarakat memberikan kontribusi pada (re)konstruksi peserta dan negosiasi identitas yang sedang berjalan. Bagaimana evaluasi tersebut mendorong atau menghalangi akses ke warisan dan budaya bahasa dianalisis berdasarkan penggunaan tuturan peserta yang dilaporkan. Artikel ini meneliti apakah PB dapat menjadi cara negosiasi dan memperoleh peran atau tidak, serta bagaimana PB membantu pelajar terpinggirkan untuk memilih dimana dan bagaimana dia berada. Artikel ini juga terlihat pada bagaimana marjinalisasi memotivasi pembelajaran bahasa, dimana peserta berusaha untuk memposisikan dirinya kembali. Penelitian ini juga menguji bagaimana hubungan kekuasaan (mahasiswa terpinggirkan dalam konteks tertentu) memainkan peran dalam proses negosiasi identitas dan pembuatan-makna diri. Hasil dari penelitian ini menyimpulkan bahwa melalui pengalaman dalam pembelajaran bahasa asing serta melakukan negosiasi makna untuk menjadi pembelajar bahasa Jepang sebagai Bahasa Asing (JFL), peserta secara bertahap bergeser ke dalam komunitas yang berbeda sebelumnya dari pengalaman belajar bahasa di mana ia mendapat tempat untuk praktek dan tidak lagi menjadi anggota masyarakat yang terpinggirkan.

Katakunci: pembelajaran bahasa, negosiasi identitas, komunitas praktik (CoP)

Language learners' world view or epistemology is embedded in their languages so that it is crucial to look at language not just as systematically organized structures, but as a reflection of complex social practice. This paper will explore how Jack, a Filipino American participant of the study, negotiates his identity through his experiences with three different languages, his L1 (English), heritage language (Tagalog), and foreign language (Japanese), by using narrative inquiry as a way to analyze the data. Jack's concomitant experience in communities of his L1, heritage language as well as Japanese language learning community will be discussed as his narratives tell his trajectories over learning and how he positions these languages in his life. The paper first discusses the theories that frame this study, and describes data collection and research methodology which encompass perspectives toward the narratives. Following that, the paper will present findings and analyze them based upon previously demonstrated theoretical positions.

\section{Language Learning as a Social Practice}

A wide range of studies on language learning and second language identity has a significant impact on this paper. This paper is situated in the current post-structuralist approach and framework of language learning. Earlier studies saw language learning as a gradual individual process of internalizing a neutral set of rules, structures, and vocabulary of a standard language (Norton, 2006, p. 504). Hence, sociocultural contexts of language learners, including power relations, were not taken into account. Similarly, the aspect of language learning as a negotiation of identity in a situated discourse was disregarded. Bakhtin $(1981,1984)$, in contrast to the traditional recognition of language learning as a individual mental process, emphasizes that language needs to be investigated as situated utterances in which speakers, in dialogue with others, struggle to create meanings. In post-structuralist studies, language is viewed as multifaceted as it possibly reflects on speaker's ideologies, cultural background, beliefs, values, and so on. According to Lave and 
Wenger (1991), "learning is an integral and inseparable part of social practice" (p. 31). In this way, researchers in the field of L2 learning and identity have conceptualized language as sets of relationships between utterances and contexts. In other words, language learners' world view or epistemology is embedded in the language so that it is crucial to look at language not as systematically organized structures, but as a reflection of complex social practice. Drawing on such theories and concepts, contextualizing learners' experiences prior to language learning (for example, what brought them to second language learning) over time and space should be equally paid attention to.

Hence, language learning is a process of socialization, and socialization is always multi-directional (Schieffelin \& Ochs, 1986, p. 165): language learners appropriate and construct their voices within the discourse to achieve subjectivity. Thus, being a novice or peripheral member of a community does not mean that $\mathrm{s} / \mathrm{he}$ is a passive receiver of information. Rather, $\mathrm{s} / \mathrm{he}$ is a part of meaning-making process of the community. This theory explicates the idea that individuals in the community are selective in terms of appropriation, interaction, and socialization, and active in constructing communal/societal epistemology. Each member brings his/her own realities no matter how legitimate or peripheral he/she is. Likewise, language learning can be perceived as a way of (re)constructing a sense of self in the community, and the notion is shared and negotiated with other members. Language learning, thus, is an act of gaining intellectual knowledge as well as making sense of utterances and meaning. Taking account of the social context of language learning sheds light on learners' process of appropriating a particular discourse while gaining their own voices.
Drawing on the aforementioned theories and concepts, contextualizing learner's experiences prior to language learning (for example, what brought them to language learning) should be accounted for. Narratives from a participant reflect his approach toward language learning (LL) as well as the motivation behind language learning. Thus, not just looking at the result of LL itself (test score, pre-test, and post-test), but also looking at a wider context of LL, such as experiences prior to LL, will facilitate understanding of what LL means to a learner. Becoming competent in a language involves more than just academic success, but also multifaceted aspects of self (sociocultural, economical, political, and historical) in a situated context.

\section{Negotiation of Meanings and Identity in CoP}

The post-structuralist approach to language learning addresses language and language learning as a process of gaining access to an agency and as a site of struggle. Language, according to Solé (2007), is not only a means of communication, but is also the place where identity is contested, as it is through language that we organize our social selves (p. 205). Rather than being solid and unidimensional, we understand identity as multiple, complex, and fluid; identity can be constructed, negotiated, deconstructed as well as reconstructed based on situated contexts and social practices. Thus, I would say it is important for language learners to gain legitimacy in formulating their own identity and negotiating meanings. Tsui (2007) thinks that participation is central to identity formation since participation as well as nonparticipation in negotiating meanings is shaped by power relationships among members of a community (p. 678). Engagement in specific aspects of social practice enables learners to contextualize conceptual structures of the community 
within. For Lave and Wenger (1991) and Wenger (1998), a community of practice $(\mathrm{CoP})$ is a set of relations among person, activity, and world, over time and in relation with other tangential and overlapping communities of practice. Members of the $\mathrm{CoP}$ are mutually engaged in an overlapping practice in the shared context. Toohey (2000) observed:

Communities may provide more or less desirable, powerful or equitable positions for participants within them, but - through the practices in which participants engage all participants learn. What they might learn is shaped by the kinds of positions they might occupy (p. 15).

With this notion, Lave and Wenger suggested the concept of "legitimate peripheral participation" (LPP) in which a novice member and a legitimate member have a different degree of engagement and access. However, throughout the process of participation and engagement in CoPs, a novice learner becomes an active member of the meaning-making process and so the form of membership transforms: as a novice learner develops his/her relations to the community, the negotiation of identity and participation is afforded.

Drawing on Lave and Wenger's notion of CoP, I will analyze how the participant's assigned position in the situated context or $\mathrm{CoP}$ affects his emotional and academic trajectories over time. Though Lave and Wenger did not look at $\mathrm{CoP}$ as a site of struggle along the way, I will explore the participant's struggle in CoP since I acknowledge that different levels of engagement and access for participation as well as nonparticipation among members exist and which could impact upon power dynamics of discourse. Unlike Lave and Wenger, I see participation is not the only choice that members can make in order to acquire legitimacy. Members negotiate their meanings in CoPs, but the negotiation does not have to be for gaining access to legitimacy. In other words, it could be done for withdrawal from the $\mathrm{CoP}$ and his/her assigned position(s). In Norton's study (2001), for example, participants took the action of "non-participation" by withdrawing from the ESL class which was "an act of resistance" (p. 165) of marginalized members in language learning CoPs. She used the term in order to describe the physical and official withdrawal of the participants from an ESL class. In this paper, however, the participant does not necessarily withdraw from attending a CoP. In other words, the notion of non-participation in this paper is borrowed to describe how the participant positions himself or is being positioned in his situated discourse.

\section{METHOD}

\section{Data Collection}

This paper is based on audio-recorded faceto-face as well as via Skype interviews with one Filipino American who was born and raised in the United States. Interviewing his family and a tutor helps to get a glimpse of how their positioning affects him in terms of his LL and other aspects of his life. The email communication with the participant regarding this topic is also a part of this paper. The participant took Japanese in college and he used to be my student and later became a good friend of mine.

Data collection was done periodically over a year from October 2008 to March 2010. Each interview/interaction lasted almost an hour and was informal as I wanted the interviews to come out of our casual daily conversation. I was already familiar with some information provided by the interviewee before these interviews. Narrative data were elicited from open-ended, semi-structured questions. All the data shown in this paper received feedback by the 
participant in order to enable him to revisit his narratives. Rather than treating the interviews just as a form of information exchange and acquisition process, I see it as "a site for collaboration and the genuine sharing of experiences" (Atkinson \& Coffey, 2002, p. 119). I regard this research opportunity not just as a longitudinal study of an individual learner or a simple process of data collection. The whole process was an ongoing coconstruction of sense-making which gives us a place to reflect on the meaning-making process.

\section{Data Analysis}

Through narrative inquiry (Alvermann, 2002; Pavlenko, 2003, 2007; Solé; 2007; Tsui, 2007), this paper will examine how the participant in the present study views his trajectories of identity formation regarding the L1 (English), heritage language ${ }^{\mathrm{i}}$ (Taga$\log$ ), and foreign language (Japanese). Power relations in discourse will be a focus of the study in order to see how the positioning affects identities. The central purpose of this paper is to better understand how one Filipino American participant negotiates a hybrid identity through his experiences in the heritage language/culture, English language/ culture, and Japanese language/culture. The paper adopts narrative inquiry as a viable method to analyze the data collected from the series of interviews with the participant. Alvermann (2002) uses the term narrative inquiry to refer to

...a variety of research practices ranging from those that tell a story of how individuals understand their actions through oral and written accounts of historical episodes (Riessman, 1993) to those that explore certain methodological aspects of storytelling (Richardson, 1997)... [that is used] as a way of understanding life and lived experiences (Cortazzi, 1993). (p. 49)
Within a Bakhtinian framework, Vitanova (2005) sees that the very creation of narratives is a polyphonic meaning-making process (p. 155). Interviewing is not just a process of acquiring data. Based upon Reissman's (1996) idea that what's important to be considered in narratives is "not truth, but trustworthiness of our interpretation" (p. 138), the narratives in the study take his reality into account rather than focusing on historical facts. Instead, the narratives conveyed through the interviews are collaboratively formulated with the active participation of the interviewer and the interviewee. In order to analyze the narratives, I take into account subject reality (Pavlenko, 2007, p. 165) with discursive approaches. With sociocultural, historical, and local background of the participant, the paper uses narratives as an important key to analyzing the participant's struggle, negotiation, and recognition of his own fluid and complex identities. Theorizing and contextualizing the participant's positioning and his ownership of agency in certain discourses needs reflection and recognition of his sociocultural background such as his experiences pertaining to his heritage language and foreign language learning.

By focusing on content and context at micro and macro levels, this paper will also highlight the impact of foreign language learning experience upon participant's conflict, negotiation, and transformation of identity. Throughout the course of discussion, the focus will be on the narratives of a participant since the stories are connected with social practices in particular contexts (Hymes, 1977). The way people make meaning together over time is recursive and iterative, so a story makes its point not just through the kind of textual evaluative strategies, but also through the web of interconnections which the narrative invokes (Maybin, 1996, p. 37). Alongside of his positioning analysis, the paper will closely look 
at how evaluation by other Filipinos within the community contributes to the participant's ongoing construction and negotiation of identity, and how those evaluations encourages or impedes his heritage language learning by analyzing participant's use of reported speech.

\section{FINDINGS AND DISCUSSION Struggles and Negotiation}

The paper will explore how the participants have been positioned in school and community discourse in terms of levels of heritage language. Participant's encounters with foreign language and transformation of hybrid identities follows.

\section{English}

Despite his fluency in English, he was registered for "Modified Primary"ii", where he spent the first four years in grade school. He recollects,

\section{Excerpt 1}

It was too embarrassing to be in the class because it was too basic for me. It was very remedial. I could speak English well because that's my native language, but they (school administrators) assumed that I have to be in that class, and they put me in it because I was Filipino.

He sees the experience as "unique" because this class was where he first felt marginalized by other students due to his fluency and competency in English compared to other students for whom English was their L2. He was "way too good" to be at this level, and other students sometimes treated him harshly because of this. He eventually started to hide his fluency in order to fit in with the group by making mistakes in reading passages which made him stay in this track longer than needed. Rymes and Pash (2001) report a phenomenon of "passing" which refers to students trying to do "being student" or pretending to understand teachers so that s/he can catch up with classmates. "Passing" is a means of accomplishing or maintaining regular, ordinary status so that his/her learning problem becomes less visible in the discourse. In this way, student's effort to pass as a good student could interfere with actual learning process and result. Like Rene, the participant in the Rymes and Pash's study, Jack in the present study played passing in order to fit into the discourse and to maintain the image of an ESL student by closely paying attention to attending discourse (e.g. the proficiency level of his classmates). Instead of passing for more competent and proficient, which is what we normally see, he was trying to pass for less competent than he was so that he can secure his position in the discourse.

\section{Tagalog}

In Excerpt 2, the researcher asked Jack how much Tagalog means to his life, and this short excerpt reveals how he views Tagalog:

\section{Excerpt 2}

A: So how do you see your proficiency level in Tagalog? How does it affect your life? Or does the language play any role in your life? J: No. No. Tagalog doesn't play much role in my life. Now, Japanese (is) more into my life because it has a major influence now. Back then, it was English. English only. Everything had to be in English. But now, if I wanna code-switch, I can code-switch with English and Japanese.

To the question asking about how Tagalog is influencing his life, Jack gave a negative reply with a strong no. The emphasis and the repetition of negative answer reflect the level of rejection to the question. But the paper cannot presume at this point whether the denial of his previous statement arises from his view of heritage 
language or his sentimental rejection of it. On the other hand, right after he made it clear of his position about his heritage language, he switched to tell how he thinks about Japanese. Again, it is very clear that how he positions Japanese by comparing it with Tagalog. Throughout the entire interview, Jack never talked about Tagalog unless being asked a question about the language. Also, he never used the word "Tagalog" at all in our conversation. The newer generation of his family members who were born and raised in the U.S. speak English only or another secondary language (e.g. Japanese). Not only Jack, but his brother and cousins learn Japanese at school.

His past experiences related to Tagalog seem to have a significant influence upon his opinions about the language. When his family had get-togethers, his older family members talked to him in English though according to him, they switched to Tagalog when they talked about something they did not want children to hear or when they gossiped about him. Although he was not competent in Tagalog, he could catch some words and phrases that led him to know that his family members were speaking about him. This experience left an impression on him that Tagalog is a language that "hurts his feelings." He also felt that he was eliminated by the older family members when they used Tagalog. Gradually, he came to think that his family members were talking about him whenever they spoke Tagalog. The fact that Tagalog did not play much of a role in his narratives can be seen in Excerpt 1. It reveals the lack of legitimacy given to languages other than English in the past. Tagalog had no place to fit in his life. He contrasts his identities in that he mentions the value of his Japanese L2 in his life after negating his heritage language. Also, he implies that his L2 is now replacing the role English used to play before learning Japanese. His life solely depending on L1 is now shifting by gaining knowledge and skills in L2.

Each language, English, Japanese, and Tagalog, have different meanings for Jack. English, his L1, plays a big role as his life largely relies on this language, and his CoP at school as well as home is formed with it. As he gains knowledge and competency, he gained access to change CoPs and his imagined community. In this way, learning Japanese for him was a means of negotiating his identity and CoP. Tagalog, on the contrary, has had less influence on him as his CoP shifts. As he gains access to claim ownership in his identity, Tagalog plays less of a role because the language itself made him feel marginalized in the past. Tsui (2007) stated that "members whose meanings are consistently rejected and whose experiences are considered irrelevant, and hence not accepted as a form of competence, will develop an identity of marginality" (p. 661). He associated Tagalog to his marginal identity in the past.

\section{Tagalog and identity: Identity as a Filipino} American and positioning

This section will explore how Jack's previous language-related experiences of being positioned by others influenced his self-positioning as well as his positioning as Filipino American in general in American society. First of all, the paper will introduce Jack's story as a non-Tagalog speaking Filipino American:

\section{Excerpt 3}

Maybe back then, it'd be nice [to learn Tagalog] so that I'd understand. There was a lot of people who speak it. That's why it'd be good to learn it. But because I didn't understand Tagalog, they [Filipino peers at school] thought, "oh, he's American" or something. They said "he's not real. He's not real." For example, when they spoke to me in Tagalog, I didn't understand, so they 
thought I wasn't real. They were like, "oh, he doesn't understand. He's not real." Especially in junior high school, Filipinos picked on me. I was like, like an outsider. They picked on me because I didn't have the look, the [Filipino] image. The image like baggy pants and designers' clothes. Actually, I wanted to be like them, tried to look like them. But it wasn't the clothes. It's the personality... their lifestyle, how they were brought up, and my interest from theirs, everything is different.

This excerpt has a lot to cover in terms of positioning based on ethnicity and language. Excerpt 3 is also full of evaluative comments through reported speech. In this narrative, reported speech is important as "it highlights the narrator's point of view by allowing the narrator to evaluate the story that is being told and introducing agency" (Sole, 2007, p. 208). Although Jack made it clear in the previous part that he is not eager to take Tagalog class, Jack was willing to understand the language in the past. He said "it'd be nice" if he could have learned Tagalog back then. This sounds like a regret: he seems to have an idea of an imagined self and in an imagined community, who speak Tagalog, which might be different from the present self. He seems to have a clear idea of how he could have been different by being proficient in Tagalog. This indicates that Jack saw language as a key to be a part of a Filipino American group. However, he was labeled as "an American" by other Filipino Americans due to the lack of his Tagalog proficiency. In his school years, Jack did not see anyone around him who were nonTagalog speaking Filipino Americans. With this fact, he acknowledged the difference between him and Tagalog-speaking peers in his situated CoP which is a crucial factor in facilitating his non-active participations status. By calling him an American, "they" alienated Jack from the group: they, from Jack's perspective, positioned Jack as other.
We see a dichotomous relationship of power dynamics between those with the language and those without whose access to the resource as well as participation is limited. Language as a powerful resource here plays a role in decisive identity construction. Lam (2004) asserts that socially constructed attributes or boundaries enable power relations among people in the group, so "a person's alignment with or opposition to a certain cultural group can be seen in how he or she adopts or resists the discourses of the group" (p. 3). From this, we can see that ethnicity does not necessarily correspond to identity: being Filipino American does not guarantee to be accepted as Filipino by the group and its CoP. In Excerpt 3, we see a clear dichotomy of "I" as a self and "they" or "people." It shows how he perceived to be labeled or marked as "not real" by using reported speech. He was even labeled as American, the ultimate exclusion from Tagalog speaking Filipino Americans. This labeling creates a boundary. In this way, language functioned as a marker either to group or to keep out Filipino Americans at school. The first part of Excerpt 3 tells us that Jack was distanced by his Filipino American classmates during entire his school years. Jack sees and tells what happened to him back then from "their" framework by positioning himself as a member of the Filipino American group.

The latter part of Excerpt 3 leads us to see how Jack sees other Filipino Americans, and how "they" see him further separates their identity. We now know that he was picked on by other Filipinos. He stated clearly that he felt like an outsider, the individual who does not belong to the Filipino American community. From his narrative, we can see his experiences with other Filipino Americans in the past, and how he felt alienated. Thus, the fact that he does not currently have many Filipino friends comes to make sense. This fact 
accelerates the othering and enlarges the gap between Jack and other Filipino students. As a high school student, he tried to learn some Tagalog words that can pass him as Filipino from his friend, but when he used the words, he didn't get any reaction from his Filipino American peers because "it wasn't a big deal" and "they could tell that I'm an Englishspeaking person by my accent, the way I talk." By finding out his English fluency doesn't allow him to be recognized as Filipino, he said he stopped trying to fit in. This again signifies that how self and peer evaluations can be important means for individuals' positioning and construction of self in the attending community:

\section{Excerpt 4}

If they don't take me in, I'm out. It was like segregation within segregation. Whites with Whites. Filipinos with Filipinos. Skaters with skaters. But me, I didn't already belong with my group, so I hang out with all the rejected people from their group...I wanted to [learn Tagalog because] if you can speak Tagalog, you're in. To them [Filipino American peers], I was like a White. In their eyes, I was White. But for White people, they see me as a Filipino.

Again, we see how the contrast between Jack and Filipinos follows socio-cultural images or stereotypes. A series of his narrative illustrates being positioned as an outsider based on "the look" he has. It is notable that the way he describes the "Filipino image" as from outsider perspectives rather than his own sense of identity. Determining that the lack of the Filipino image contributes him to be alienated, Jack made an attempt to fit in to the image of Filipino Americans. But again, he discovered that what makes him "not real" was not the superficial image. He explains that it was language as well as his personal interests. From the narrative, we can see he wished he could have spoken Tagalog, an ethnic iden- tity marker of Filipinos, in the past so he could understand "their" language. He tried to fit in to the Filipino image by wearing baggy pants and designer's clothes. Excerpt 4 is a powerful reminder that race or ethnicity is socially constructed, rather than biological on the contrary to its stigmatized, but wide-spread stereotypical image. García (2009) quotes,

Barth (1969) sees ethnicity not as unchanging cultural traits, but as situational and in relationship to the ethnic boundaries that define social interactions and, in turn, maintain these boundaries... and Max Weber (1946) has warned that ethnicity is not solely the process of identity construction, but is also the product of the characteristics resulting from such a process.

Despite his heritage or ethnicity, linguistic and physical feature (in this case, notcompetent in Tagalog and not having a "Filipino style" look" played a vital role in the discourse "as it functions to establish the group boundaries and delineate insider and outsider status" (Wallace, 2004, p. 203). He even tried to fit in to the stereotypical image of Filipino in order to be a part of "them" until he came to conclude that his personal interest deep inside of him was not Filipino enough.

In addition to the peer-evaluation, Jack has been constantly getting comments by his family members. Most of his older family members use Tagalog as their L1, and although they can speak English, he has felt that there is "a barrier" between him and them. He compared himself with his cousin whose L1 is Tagalog. Jack has observed that instead of talking to him, older family members talk more comfortably with his cousin because he thinks they share more in common. Not being recognized as "Filipino enough" gave Jack a non-legitimate status to 
practice Filipino-ness. Even though he claims that he has some Filipino traits in terms of cultural values, his Filipino-ness was not taken for granted by legitimate members. Assigned position by others as a non-legitimate or a peripheral member in his $\mathrm{CoP}$ further marginalized him. The more Filipino traits you hold, the more access to recognition and legitimacy you gain. From this perspective, he was marginalized in his $\mathrm{CoP}$ as a result of unequal power relations.

Jack's non-participation in the assigned CoP entails both voluntary and ascribed nature of identity negotiation and positioning through which learners develop multiple, often hybrid identities in their imagined communities.

In his attributed CoP where Filipinoness is the norm, he was always a nonFilipino or "not real" member with which non-participation was the most option he could take. His identity was formed with a presupposition of what he is not rather than what he is. This does not allow him much space to negotiate and gain agency or legitimate status within the community because the possibility of achieving the status is low due to the fact that what he is not was more taken into account than what he is. Despite the fact that it hindered his access to the legitimate status, his non-participation eventually served as a springboard to fully involved in his negotiated and imagined CoP.

\section{The Effects of Second Language Learning on Negotiation of Identity}

Japanese

In Excerpt 5, the researcher asked Jack if he wanted to learn Japanese earlier as well as what he would have done if school offered a Tagalog course:

\section{Excerpt 5}

Probably yes if it [Tagalog] was earlier, like maybe in the elementary [school]. That'd be kinda cool. That would be better, too. The soon, earlier the better. But Tagalog [if Tagalog was offered in college], probably no. I'm not really interested in. I don't know why. But even my grandparents talked to me in English, so didn't have much chance to learn Tagalog. Tagalog is something they speak, not the one I speak.

First of all, his answer to the question is worth paying attention to, since the narrative here tells a story. His speech shows us his standpoint of L2 learning: the earlier, the better. The narrative clearly shows that he wanted to be the one to learn L2 at an early age. His answer also suggests how he imagines himself to be if he learned L2 earlier and how he sees his current L2 ability. Then, the researcher switched to another question to see if he was eager to take Tagalog if he had a choice. Again, his answer did not show any interest in his heritage language. He answered the question by stating how much he likes Japanese language. Thus the characteristic of his speech implies that he positions his heritage language and L2 on totally opposite sides: Japanese as a target of interest while Tagalog as a language he did not wish to learn.

During the interview, Jack mentioned that he has always wanted to take Japanese classes ever since he entered college, but he thought it would be very challenging since he had no experience in learning an Asian language. He recollected that he was not "brave enough." However, his friends wanted to take Japanese, so he decided to enroll in a class with his friends. He regarded JFL classes totally different from all the other classes: he was satisfied with passing grade before, but for JFL classes, he wanted to try his best to get a better grade so that he can "go to Japan, be able to communicate, to function there, and speak Japanese there and get a job." His imagined community apparently played a positive role in his language learning experience. He engaged in 
varieties of activities related to JFL class: participating in Japanese roundtable, attending Japanese Culture Club (JCC) every other week at school, and taking part in an annual Japanese speech contest. All of those activities were not mandatory, but he was dedicated in all of them in order to achieve fluency in his target language. His dedication to JFL class helped him to gain recognition and legitimacy in the CoP: he was known as a regular member of JCC and being known by other members and instructors. Through his active participation in the language learning community, he became a legitimate member of this CoP. Bartlett (2007) demonstrates that as Maria, the participant of her study, became to be known as a good student from teachers and peers, her opportunities to learn increased as well. Like Maria, Jack made himself visible to the other members of the learning discourse which heightens his learning opportunities. His Japanese tutor, Marika, recalls that he was not an " $A$ " student who always succeeded in quizzes and exams. He often had problems in remembering grammar rules and seemed to struggle with learning Japanese though he tried to learn and never gave up. She still remembered him because he rarely missed her tutoring sessions. This shows that failing in tests does not necessarily hamper learner's investment in the language acquisition process. Jack's visibility and legitimacy in the CoP enabled him to expand the opportunity to learn Japanese as he recalled, "Once you have the foundation, they [classmates] listen to me, pushing me to speak Japanese. We all had one goal. We all helped each other." During tutoring hours, he helped his classmates by correcting errors in assignment by which his friend once called him "the Japanese expert." This assumes a position of legitimate member of the community who has direct access to the knowledge, agency, and power that legitimate members need. As Wortham (2006) argues, social positioning and learning opportunities are mutually influenced by each other. Through participating in extracurricular activities, Jack negotiated his positioning and expanded recognition of his agency within the community.

\section{Learning Japanese as transition}

The previous section shows Jack's experience as a non-legitimate member of any CoP he participated in: throughout his life, he felt that he did not belong to the American community nor Filipino American community. According to Jack, he was "in-between." Not being a legitimate member of $\mathrm{CoP}$ had a significant impact upon his identity formation and negotiation. Lack of sense of affiliation with his heritage language hampered his sense of self as a member of Filipino American community.

The paper now focuses on how learning Japanese has transformed his identity and CoP. Engaging in second language learning resulted in him becoming a legitimate member of different discourse. And this became a "crucial stepping stone toward recovery of agency" (Pavlenko \& Lantolf, 2000, p. 168). $\mathrm{He}$ gave up his former $\mathrm{CoP}$ of which he did not gain access to legitimacy by metaphorically withdrawing from it so that he could gain more access to a new discourse where he gains recognition. After learning Japanese for a year, he visited Japan, one of his imagined communities, for the first time. Yet his imagined community of Japan is a vision of a very private nature, the vision, as Kanno \& Norton discussed (2003, p. 243), profoundly affects learner's investment in the target language and his concomitant actions and learning trajectories. His experience in the imagined community of Japan was "the best." Despite his short-term stay in Japan (45 days), he affiliates himself with local Japanese people: he found that there are several things, such as the way he dresses and way of thinking, they share in 
common. Jack felt he "blended in 'their' culture." One example he gave

\section{Reconceptualizing languages and identities}

For Jack, learning Japanese was not just a process of internalizing a set of rules and grammar. Rather, it also functioned as a means of negotiating and reconstructing his identity and $\mathrm{CoP}$ in real practice and his imagination. He is engaged in the real-world language learning CoP by actively participating in various activities to make himself visible within the Japanese CoPs. The role of his imagined community facilitated his language learning to eventually blend into Japanese society. How he views his heritage language and culture has changed throughout the process of language learning: Jack is gradually getting over his feeling towards his heritage language and community based on negative experiences as he becomes more competent and confident in an alternative CoP. One example is that as he developed his Japanese language abilities, he started to talk about Filipino culture more than ever before.

Language learning and appropriation of target language and culture is not a single factor brought him to the acceptance of his heritage language and culture, but the experience as a language learner "helped [him to] see things differently from different perspectives." The appropriation of his experience as a language learner reshaped his understanding of heritage language and culture and generated reconciliation with them.

\section{CONCLUSION}

How Jack contextualizes himself in his past, present, and future CoP plays an important role in how he positions himself in his situated practice. This paper tried to convey how the Filipino American participant negotiates his identity through his experience in heritage language/culture and foreign language learning and its culture by closely analyzing participant's views and experiences within the community. The paper also investigated the impact of foreign language learning experience upon the participant's conflict, negotiation, and transformation of identity. By analyzing how the Filipino American discourse views or evaluation of the participant contributes to the participant's ongoing construction and negotiation of identity, we now see that what he experienced throughout the negotiation of identity is bound up with how other people attribute an identity to the individual whether they wish it or not (Byram, 2008, p. 65). Participant's reproduction and framing of other people's and his own voices enable him to explore different perspectives within society. Language learning trajectories accommodate his positive shift in his academic career. It seems that negotiating CoP and gaining legitimacy there empowered him to practice agency in another CoP. Language learning, thus, released the sense of marginalization which somewhat was embedded in him.

Alongside Jack's learning trajectories, the paper looked at how power relationships play a role in the process of negotiation of identity and meaning-making of self. The paper focused on how the participant establishes who he is in his narratives through language. Jack has very limited knowledge in Tagalog which triggered distancing from the Filipino American community. Moreover, he recognized the gap lying between him and general images of Filipinos as well as other Filipino Americans in terms of his personal interest, appearance, ways of thinking, and language background. Thus, the evaluation or positioning the participant gets from other members of his CoPs seems to play a huge role in how he negotiated his identity. However, Jack no longer needs to stick with his non-legitimate status of his former CoP. By engaging in various activities related to his Japanese class, he gained recognition by 
his teachers as well as other students which led him to acquire a legitimate status in his language learning $\mathrm{CoP}$. He rather chooses the CoP in which he holds a legitimate membership. This process allows Jack to become more accepting of Filipino culture and Filipino American community. He said, "I'm learning other language, other culture, so I guess I have to be open to my culture, too." Thus, his experience in language learning $\mathrm{CoP}$ and an imagined community was a catalyst for him to leave the negative past experience behind and achieve an alternative identity which he holds as legitimate.

This study addressed the participant's past experience as a marginalized individual as well as the present position as a legitimate member and the future affiliation and self as a fluent speaker. However, it is important to mention that his current imagined community and legitimacy in his CoP would not be fixed as negotiation, (re)construction, and (re)positioning of self is constantly changing and evolving. Identities are complex, fluid, and sometimes fragile that can be influenced by power relations while they could react to discourses as a form of resistance. It is tempting to define one's identity and

i

The author acknowledges that there have been critical views on the use of the term heritage language, and alternative terms have been suggested. Using the label heritage itself has been challenged by many and has been regarded as extremely negative -even offensive or counterproductive- by some researchers (Van Deusen Scholl, 2003). Baker and Jones (1998) states that the term heritage language points more to the past and less to the future... so that the term fail to give credit to the value of modern language. The participant and I, however, view the term in a positive sense that heritage is something being passed on for generation to generation so that we recognize heritage language as a vital part of cultural affiliations of groups of people.

Modified Primary course, according to Jack, was for those students who are from the family whose L1 positions within $\mathrm{CoP}$ or overgeneralize meaning-making process of individuals or ethnic groups, but we researchers have to be aware that data we see through our research is one part of individuals and does not reflect everything.

Tsui (2007) discusses how recognition and legitimacy are important factors of identity formation. These two factors influence one's affective investment and it seems that the more sense of belongings you feel, the more successful you can be in a community (Morita, 2004) because you have better access to the source of power within a community. This paper suggests that what is important in language learning and its trajectories is to assure students a classroom with a sense of belonging as classroom dynamics affect students' negotiation of membership in immediate and imagined communities. Students envision imagined self in an imagined community based upon how they position as well as how they are positioned in a situated setting. The sense of belonging in classroom provides social support and enables students' interdependent study which allows every one of them as a part of whole to contribute to learning.

is not English. The class provided students with basic English reading and writing.

\section{REFERENCES}

Alvermann, D.E. (2002). Narrative approaches. In Kamil, M.L., Monsenthal, P.B., Pearson, P.D., \& Barr, R. (Eds.). Methods of literacy research: The methodology chapters from the Handbook of Reading Research V. III. New Jersey: Lawrence Erlbaum. Atkinson, P. \& Coffey, A. (2002). Revisiting the relationship between participant observation and interviewing. In Gubrium, J.F. \& Holstein, J.A. (Eds.), Handbook of interview research (pp. 
801-814). Thousand Oaks, CA: Sage Publications Ltd.

Bakhtin, M.M. (1981). Discourse in the novel. In M. Holquist (Ed.) The dialogic imagination: Four Essays by M.Bakhtin (trans. C. Emerson and M. Holquist). Austin, TX: University of Texas Press.

Bakhtin, M. (1984). Problems of Dostoevsky's poetics (trans.C.Emerson). Minnesota: University of Minnesota Press.

Bartlett, L. (2007). Bilingual literacies, social identification, and educational trajectories. Linguistics and Education 18, pp. 215-231.

Byram, M. (2008). The intercultural speaker: Acting interculturally or being bicultural. In Foreign language education to education for intercultural citizenship. (pp. 57-73). Clevedon: Multilingual Matters.

García, O. (2009). Bilingual education in the $21^{\text {st }}$ century: A global perspective. West Sussex, UK: Wiley-Blackwell.

Hymes, D. (1977). Foundations in sociolinguistics: An ethnographic approach. London: Tavistock.

Kanno, Y. \& Norton, B. (2003). Imagined communities and educational possibilities: Introduction. Journal of Language, Identity, and Education 2(4), pp. 241-249.

Lam, W.S.E. (2004). Border discourses and identities in transnational youth culture. In J. Mahiri (Ed.), What they don't learn in school: Literacy in the lives of urban youth. New York: Peter Lang Publishers.

Lave, J., \& Wenger, E. (1991). Situated learning: Legitimate peripheral participation. Cambridge, England: Cambridge University Press.

Maybin, J. (1996). Story voices: The use of reported speech in 10-12-year olds' spontaneous narratives. Current Issues in Language \& Society, 3(1), pp. 36-48.

Morita, N. (2004). Negotiating participation and identity in second language academic communities. TESOL Quarterly 38(4), pp. 573-603.

Norton, B. (2006). Identity as a sociocultural construct in second language education, In Cadman, K. \& O'Regan, K (Eds.), TESOL in Context [Special Issue], pp. 22-33.

Norton, B. (2001). Non-participation, imagined communities, and the language classroom. In M. Breen (Ed.), Learner contributions to language learning: New directions in research (pp. 159-171). Harlow, England: Pearson Education.

Pavlenko, A. (2003). "I never knew I was a bilingual": Reimagining teacher identities in TESOL. Journal of Language, Identity, and Education, 2(4), pp. 251-268.

Pavlenko, A. (2007). Autobiographic narratives as data in applied linguistics. Applied Linguistics 28(2), pp. 163-188.

Pavlenko, A., \& Lantolf, J. (2000). Second language learning as participation and the (re) construction of selves. In J. P. Lantolf (Eds.). Sociocultural theory and second language learning. (pp. 155-177). Oxford, England: Oxford University Press.

Reissman, C. K. (1996). Narrative analysis. Thousand Oaks, CA: Sage

Rymes, B. \& Pash, D. (2001). Questioning identity: The case of one secondlanguage learner. Anthropology \& Education Quarterly, 32(3), pp. 276-300.

Schieffelin, B.B., \& Ochs, E. (1986). Language socialization across cultures. Cambridge: Cambridge University Press.

Solé, C. R. (2007). Language learners' sociocultural positions in the L2: A narrative approach. Language and 
Intercultural Communication 7, pp. 203216.

Toohey, K. (2000). Learning English at school: Identity, social relations and classroom practice. Clevedon, UK: Multilingual Matters.

Tsui, A.B.M. (2007). Complexities of identity formation: A narrative inquiry of an EFL teacher. TESOL Quarterly 41(4), pp. 657-680.

Vitanova, G. (2005). Authoring the self in a non-native language: A dialogic approach to agency and subjectivity. In J.K. Hall, G. Vitanova, \& L. Marchenkva (Eds.), Dialogue with Bakhtin on second and foreign language learning (pp. 149-169). Mahwah, NJ: Lawrence Erlbaum.

Wallace, K. R. (2004). Situating multiethnic identity: Contributions of Discourse theory to the study of mixed heritage students. Journal of Language, Identity, \& Education 3(3), pp. 195-213.

Wenger, E. (1998). Communities of practice: Learning, meaning, and identity. Cambridge, England: Cambridge University Press.

Wortham, S. (2006). Learning identity: The joint emergence of social identification and academic learning. New York: Cambridge University Press. 